University of Rhode Island

DigitalCommons@URI

The Rhode Island Current Conditions Index

Economics

$9-1-2020$

\title{
Rhode Island Current Conditions Index - September 2020
}

Leonard Lardaro

University of Rhode Island, lardaro@uri.edu

Follow this and additional works at: https://digitalcommons.uri.edu/ricci

Part of the Econometrics Commons

Terms of Use

All rights reserved under copyright.

\section{Recommended Citation}

Lardaro, Leonard, "Rhode Island Current Conditions Index -- September 2020" (2020). The Rhode Island Current Conditions Index. Paper 212.

https://digitalcommons.uri.edu/ricci/212

This Newsletter is brought to you for free and open access by the Economics at DigitalCommons@URI. It has been accepted for inclusion in The Rhode Island Current Conditions Index by an authorized administrator of DigitalCommons@URI.For more information, please contact digitalcommons-group@uri.edu. 


\title{
CURRENT CONDITIONS
}

\section{LEONARD LARDARO, URI}

\author{
Available Online: http: / www.Ilardaro.com/current.htm \\ Twitter: @ladardo
}

VOL XXVIT

NUMBER 10

SEP 2020

When the pandemic hit in late February and early March, it was readily apparent to me even at that time that Rhode Island had entered into a deep recession, leading me to make a recession call. Waiting for the usual confirmation "signals" was not necessary, since we had never before experienced a forced recession. If one wants to look at what has historically been the recession signal at the state level for Rhode Island, it is six or more consecutive Current Conditions Index values below the neutral value of 50 . Guess what? We achieved that point last month. For September, the CCI once again remained below 50, stuck at its recent plateau of 25 for the fourth consecutive month. So, as both determinations show, Rhode Island is in a recession at the present time, and has been in a recession since March. But, unlike all of the cyclical recessions of the past, the levels of numerous indicators didn't just gradually fall to levels below where they had been; they fell much farther and a great deal faster than we had ever witnessed in the past. And I include "in the past" Rhode Island's "mini-depression" of 1991

What then, will constitute a recovery? How will we be able to identify it when it occurs? A recovery is not a return to the levels of activity that existed prior to the recession. In other words, it is not necessarily a return to "normal" times. Instead, it is a sustained period of increasing overall economic activity. This time, since activity levels have fallen so far, we will almost certainly be in a recovery, as things improve on a sustained basis, but at a relatively slow pace. Why? Because Rhode Island's state government has never adequately adapted to the realities of managing a post-manufacturing economy, where economic growth must be continually earned based on informed and

\begin{tabular}{|l|r|}
\hline \multicolumn{2}{|c|}{ CCI Indicators - \% Change } \\
\hline Government Employment & -2.3 \\
\hline US Consumer Sentiment & -13.9 \\
\hline Single-Unit Permits & -14.5 \\
\hline Retail Sales & 6.8 \\
\hline Employment Services Jobs & -29.3 \\
\hline Priv. Serv-Prod Employment & $-\mathbf{8 . 3}$ \\
\hline Total Manufacturing Hours & -2.6 \\
\hline Manufacturing Wage & 4.5 \\
\hline Labor Force & 0.8 \\
\hline Benefit Exhaustions & $1,974.0$ \\
\hline New Claims & 546.6 \\
\hline Unemployment Rate (change) & $\mathbf{7 . 0}$ \\
\hline \multicolumn{2}{|c|}{ Y Improved Value } \\
\hline
\end{tabular}

proactive policy, as a state continually stives to improve itself. Purchasing expensive jobs and hiring Brookings to generate studies of what they believe we need to do had clearly failed prior to this recession, as we remained largely stuck at the 2015 level of real GDP. In light of this, I strongly believe that it will take 3-5 years before Rhode Island returns to its pre-pandemic levels of activity (which wasn't exactly much to brag about). Therefore, expect a painfully slow recovery when it does occur, one where most people will probably remain unconvinced that a recovery is actually occurring.

Measuring the likelihood of our being in a recovery will be most effectively be gauged by following month-to-month changes in my CCI. For September, while the CCI based on yearly changes remains convincingly in contraction territory (at 25), the monthly CCI (below) has for the first time since the pandemic began moved into expansion territory, at 67 . If we can sustain above-50 values, we will be moving towards or in a recovery. Unlike cyclical recessions, though, we won't need to rely primarily on improving financial conditions. This time, everything hinges on COVID containment, an effective vaccine, fiscal and monetary policy, all of which are beyond Rhode Island's direct control.

My worry is that two key non-survey based CCI indicators are moving in the wrong direction: Both Benefit Exhaustions, which reflects long-term unemployment and New Claims, the best measure of layoffs, have begun to oncer again move higher.

\begin{tabular}{|l|r|r|}
\hline CCI Indicators - Monthly\% Change \\
\hline Government Employment & -1.1 \\
\hline US Consumer Sentiment & 6.4 & Y \\
\hline Single-Unit Permits & -5.2 \\
\hline Retail Sales & 4.6 & Y \\
\hline Employment Services Jobs & 1.5 & Y \\
\hline Priv. Serv-Prod Employment & 0.3 & Y \\
\hline Total Manufacturing Hours & 3.6 & Y \\
\hline Manufacturing Wage & 0.8 & Y \\
\hline Labor Force & 3.8 & Y \\
\hline Benefit Exhaustions & 139.3 \\
\hline New Claims & 29.5 \\
\hline Unemployment Rate (change) & -2.4 & Y \\
\hline \multicolumn{2}{|c|}{ Y = Improved Value } \\
\hline
\end{tabular}

$\begin{array}{rcc}\text { LABOR FORCE: } & \text { SEP 2020 } & \text { Peak (1/2007) } \\ \text { Participation Rate } & 64.7 \% & 68.6 \% \\ \text { Employment Rate } & 57.9 \% & 65.4 \%\end{array}$

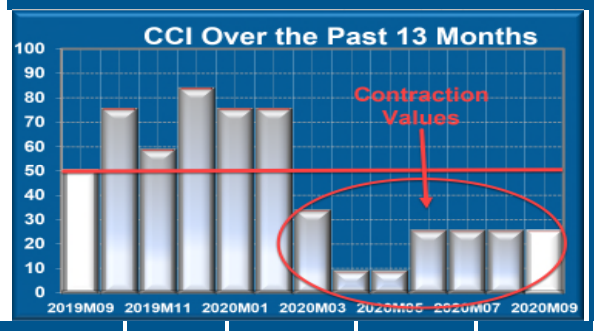

DLT SEP 2020 Employment $(\mathbf{S A}, \mathbf{Y} / \mathbf{Y})$

Gain 1,400 Loss 36,200 Net Chg (34,800)

\begin{tabular}{|c|c|c|c|c|c|c|c|c|c|c|c|c|}
\hline & Jan & Feb & Mar & Apr & May & Jun & $\mathbf{J u}$ & Aug & Sep & Oct & Nov & Dec \\
\hline 2019 & $58 \downarrow$ & $50 \uparrow$ & 58 & $50 \downarrow$ & $50 \downarrow$ & $58 \downarrow$ & $75 \downarrow$ & 67 & $50 \downarrow$ & $75 \downarrow$ & $58 \downarrow$ & $83 \downarrow$ \\
\hline 2020 & 75 & 75 & & & & $\uparrow$ & & 25 & 5 & & & \\
\hline
\end{tabular}

Gopyright ( 2019,2020 Leonard Lardaro, Ph.D. All rights reserved. 